\title{
STRATEGIC PARTNERSHIP IN FOSTERING INTERNATIONAL VET COOPERATION
}

\section{Veroniia Martyniuk ${ }^{1}$ Arturs Homins ${ }^{2}$}

\author{
DOI: https://doi.org/10.30525/978-9934-588-11-2_53
}

The present paper deals with the problem of the international cooperation development between European VET institutions and Ukrainian vocational educational establishments. Czechowska, L. (Czechowska, 2013, p. 48) draws our attention to the fact that in a professional Thesaurus the most commonly used interchangeable terms are: strategic partnership, strategic alliance, strategic cooperation, close partnership, special relations/particular relations.

It should be mentioned that in the area of international politics the term strategic partnership (Blanco, L. F. 2016) is viewed as a label and mechanism of differentiation and hierarchization; (ii) as a normative instrument to advance a 'structural foreign policy' and (iii) as a constitutive speech and positioning act.

The focus of our attention is Latvia / Ukraine Strategic Partnership and the principles of its successful implementation in the sphere of vocational education and training (VET). Strategic Partnership (here $S P$ ) of Latvian and Ukrainian VET professionals is fostered to support the development, transfer and/or implementation of innovative practices as well as the promotion of joint initiatives in cooperation, peer learning and exchanges of experience at the EU level. We agree with Czechowska, L. (Czechowska, 2013, p. 42) that a determinative issue here is the parallel maintenance of institutional exibility and long-term exceptionally close relation between transnational VET partners.

The Strategic Partnership between Rīgas Tūrisma un radošās industrijas tehnikums (here RTRIT) and Regional center of VET education in Chernivtsi oblast (here NMC $P T O)$ is transnational, it engages two VET institutions - from Latvia and Ukraine. The SP under review is formalized in bilateral agreements, which include transnational VET policy coordination, professional discussions aimed at building up bilateral relationships, different multiplier events, etc.

Educational component of the bilateral agreements is aimed at coordinating practical guidelines of the target transnational cooperation:

- educational services transfer, compatibility of programs for the training of skilled workers in the professional sphere of activity;

- Internship-exchange of VET professionals / students within the framework of educational programs;

- academic and methodological support in accordance with the modern trends of European VET education development;

\footnotetext{
${ }^{1}$ Chernivtsi High School of Commerce Affiliated with Kyiv National University of Trade and Economics, Ukraine

${ }^{2}$ Rīgas Tūrisma un radošās industrijas tehnikums, Latvia 
- implementation of the distance education system between the partners;

- practical training and sharing experience;

- participation in multiplier events, skills competitions, workshops and training camps.

Besides, the content of the target bilateral agreements reckons in the issues of the counties' cultural diversities, economic changes caused by the globalisation, differences in social and political environment.

The budget for the cooperative management and events implementation is capped to 2 participating organisations - RTRIT (Riga, Latvia) and NMC PTO (Chernivtsi, Ukraine). This type of transnational partnership combines school exchange programmes, supporting good VET practices and peer learning. Naturally, the target managerial staff concentrates the SP participants' attention on disseminating innovative ideas, practices and methods as well as intellectual outputs.

The key strategies of the target SP intellectual outputs are: transnational cooperative management, finance logistics, innovative ideas implementation, as well as caring about the quality of VET collaboration, quantity of events and programmes deliberately tailored to the needs of the target SP groups.

The SP in question demonstrates a lot of advantages that prove the ideas of the Erasmus+ Programmes, namely strategic partnership between RTRIT (Riga, Latvia) and NMC PTO (Chernivtsi, Ukraine):

- strengthens key competences in initial and continuing VET education including common methodologies for introducing those competences in curricula, as well as for acquiring, delivering and assessing the learning outcomes of those curricula;

- establishes, develops and supports the arrangements for the preparation, training and participation of VET learners and staff in international, national, regional and sectoral skills competitions, while working closely together with businesses, VET providers, chambers and other relevant stakeholders;

- supports individuals in acquiring and developing basic skills and key competences

promotes social and educational value of European cultural heritage;

- contributes to job creation, economic growth and social cohesion;

- rewards European excellence in VET teaching and skills development.

Notwithstanding the foregoing, the VET professionals-partners face some difficulties with coordinating the events of the bilateral agreements. The SP organizers do their best to avoid such 'icebergs' as: sporadic cases of local VET incompetency; possible lack of professional enthusiasm and motivation; difference in technological possibilities; poor financing and logistics; low level of ESP competency, etc.

Therefore, as we see, the target SP is linked to the current priority of Europe 2020 VET strategies [3]. Both RTRIT / NMC PTO VET professionals and students surely gain benefits from their transnational professional cooperation. This type of strategic partnership is flexible and open to being structured in different ways, according to the underlying condition of a bilateral relationship. 
Moreover, the innovative Strategic Partnership between Latvian and Ukrainian VET professionals demonstrates their volition tobalance and strengthen correlation between the European VET education and global labour market.

\title{
References:
}

1. Blanco, L. F. (12 Feb. 2016). The functions of 'strategic partnership' in European Union foreign policy discourse, Journal Cambridge Review of International Affairs, 29(1). 36-54. Reterieved from: https://www.tandfonline.com/doi/ref/10.1080/09557571.2015.1126055?scroll=top

2. Czechowska, L. (January 2013) The concept of strategic partnership as an input in the modern alliance theory, The Copernicus Journal of Political Studies 2013, No. 2 (4). 36-51. Retrieved from: https://www.researchgate.net/publication/264257630_The_concept_of_strategic_partnership_as_an_ input_in_the_modern_alliance_theory

3. Strategic Partnerships in the field of education, training and youth. Retrieved from: https://ec.europa.eu/programmes/erasmus-plus/programme-guide/part-b/three-key-actions/keyaction-2/strategic-partnerships-field-education-training-youth_en

\section{THE PERFORMING AND PROFESSIONAL COMPETENCE OF THE FUTURE SPECIALISTS IN MUSICAL ART}

\author{
Oksana Tsuranova ${ }^{1}$ \\ Olena Pohoda ${ }^{2}$
}

DOI: https://doi.org/10.30525/978-9934-588-11-2_54

The modern requirements for training specialists require a new approach to the content of education, an update of the educational repertoire, especially by means of adding the compositions of domestic composers, ancient and modern masters, as well as the change of the approach to teaching the piano in accordance with the requirements of the modern education.

The future teacher of musical art needs to be able to play the piano freely enough to influence the upbringing and spiritual development of the younger generation through the performance of compositions on the instrument by the means of musical art. It is in the education of a harmonious person that the purpose and content of the profession of the teacher lies.

The purpose of the work is to identify some ways of forming the performing and professional competence of the future specialists in musical art. In this sense, some provisions regarding the complex of elements of musical-creative, musical-analytical, general-pedagogical and psychological context have been considered.

\footnotetext{
${ }^{1}$ Public Institution «Kharkiv Humanitarian Pedagogical Academy» Kharkiv Regional Council, Ukraine

${ }^{2}$ Public Institution «Kharkiv Humanitarian Pedagogical Academy»

Kharkiv Regional Council, Ukraine
} 